Supporting information for:

\title{
Strong Enantiomeric Preference on the Macroion-Counterion Interaction Induced by Weakly Associated Chiral Counterions
}

Ehsan Raee, ${ }^{\dagger}$ Hui Li, ${ }^{\dagger}$ Xinyu Sun, ${ }^{\dagger}$ Putu Ustriyana, ${ }^{\dagger}$ Jiancheng Luo, ${ }^{\dagger}$ Jiahui Chen, ${ }^{\dagger}$ Nita Sahai, ${ }^{\dagger}$ and Tianbo Liu*, $\dagger$

Department of Polymer Science, The University of Akron, Akron, OH 44325, United States

*corresponding author Email: tliu@uakron.edu

Table of Contents

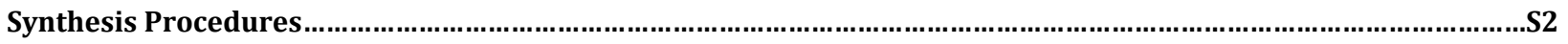

Synthesis of 3,5-di((pyridine-4yl)phenyl)-methanol...........................................................................................

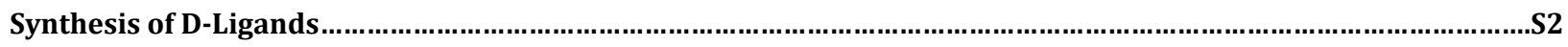

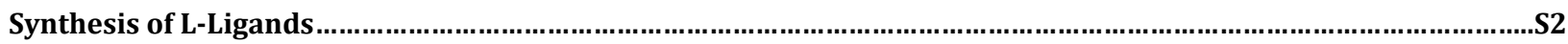

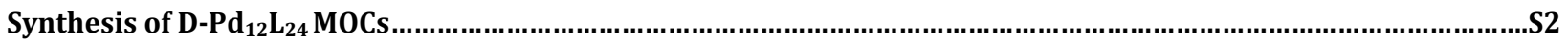

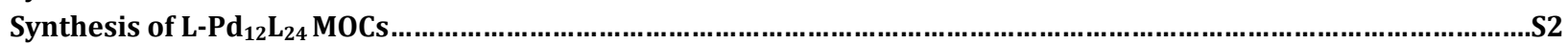

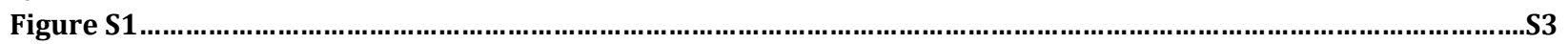

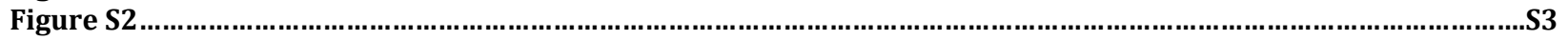

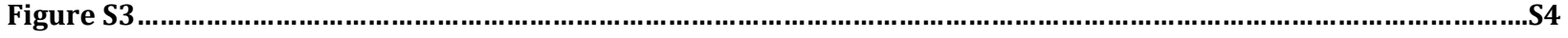

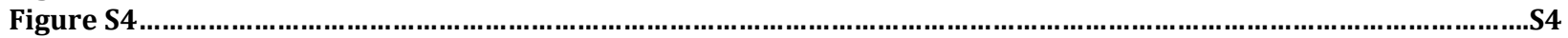

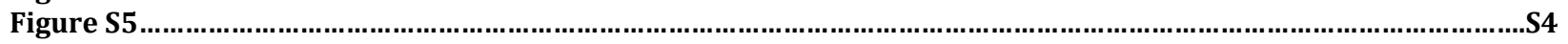

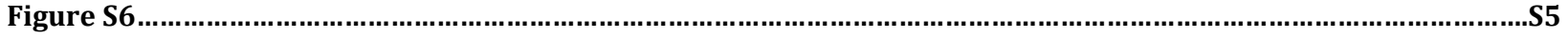

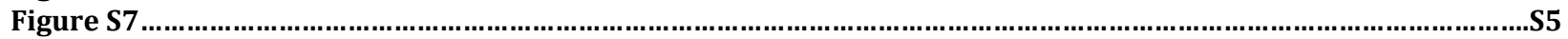

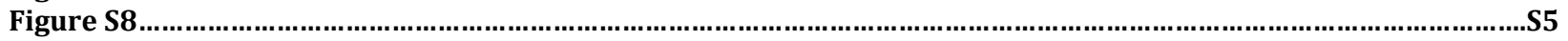

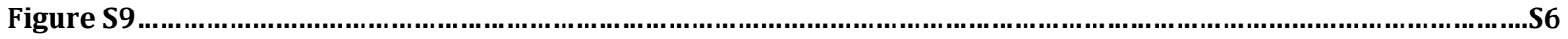

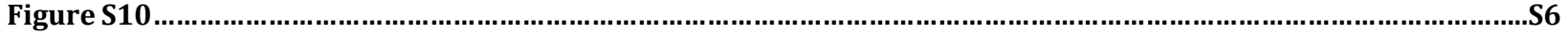

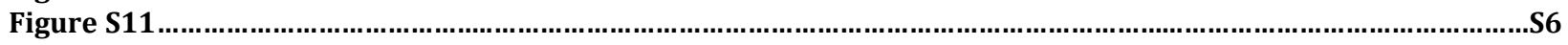

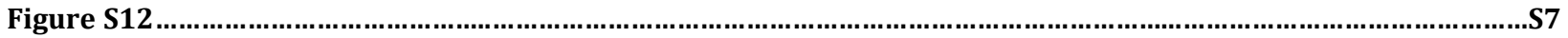

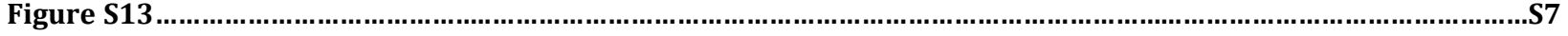

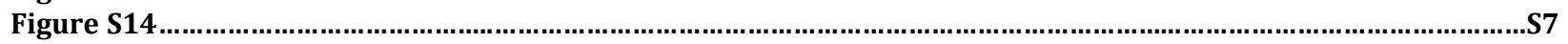

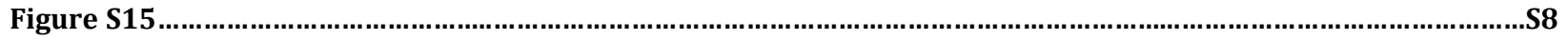

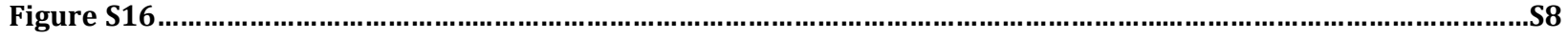

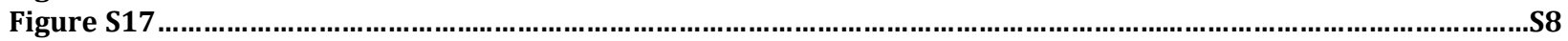

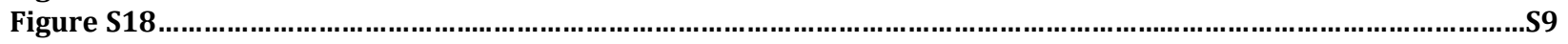

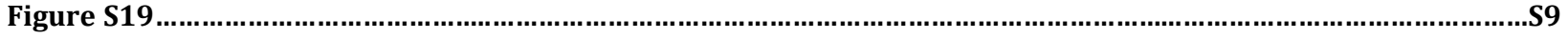

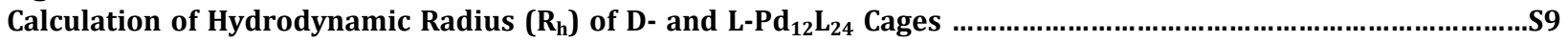

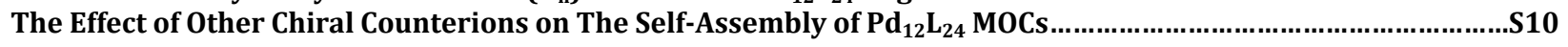

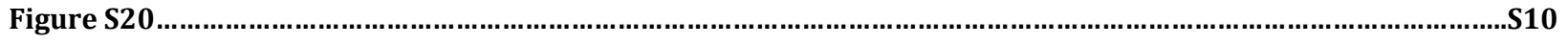

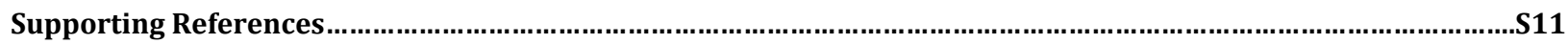




\section{Synthesis Procedures Synthesis of 3,5-di((pyridine-4yl)phenyl)-methanol}

For the synthesis of the ligands, first we synthesized 3,5-di((pyridine-4yl)phenyl)-methanol according to a previously reported procedure ${ }^{1}$. Briefly, 3,5-dibromobenzyl alcohol $(0.442 \mathrm{~g}, 1.66 \mathrm{mmol})$, pyridine-4- boronic acid pinacol ester $(0.750 \mathrm{~g}, \quad 3.66 \mathrm{mmol})$, potassium carbonate $(2.297 \mathrm{~g}, 16.6 \mathrm{mmol})$, and tetrakis(triphenylphosphine)palladium $(0.192 \mathrm{~g}, 0.166)$ were added to a round flask equipped with a magnetic stirbar, which was shut, evacuated and refilled with nitrogen three times. Anhydrous $N, N$-dimethylformamide (DMF, $13.5 \mathrm{~mL})$ and de-ionized water $(0.280 \mathrm{~mL}, 15.5 \mathrm{mmol})$ which had first been sparged with argon for 30 min were added to the flask. The flask was heated in an oil bath for $60 \mathrm{~h}$ at $100^{\circ} \mathrm{C}$, contents of the flask were filtered and washed with chloroform. The filtrate was washed with water and dried over anhydrous sodium sulfate, then concentrated mixture was obtained by rotary evaporation. The crude material was subjected to column chromatography $\left(\mathrm{CH}_{2} \mathrm{Cl}_{2}: \mathrm{MeOH} 20: 1\right)$, pale yellow solid was obtained as pure product after drying in the vacuum $(0.1966 \mathrm{~g}, 45.18 \%$ yield). ${ }^{1} \mathrm{H}$ NMR (500 MHz, DMSO- $\left.d 6,25^{\circ} \mathrm{C}\right): \delta 8.71(\mathrm{~d}, 4 \mathrm{H}), 8.08(\mathrm{t}, 1 \mathrm{H}), 7.85(\mathrm{~m}, 6 \mathrm{H}), 5.40(\mathrm{t}, 1 \mathrm{H}), 4.68(\mathrm{~d}, 2 \mathrm{H})$.

\section{Synthesis of D-Ligand}

In order to introduce chirality to metal organic cages, we followed the same procedure used before ${ }^{2}$ and equipped the ligands with Boc-Ala (3,5-di(pyridin-4-yl)benzyl (tert-butoxycarbonyl)-D-alaninate). A mixture of Boc-D-Ala-OH (85.1 mg, $0.450 \mathrm{mmol}$ ) and $N, N^{\prime}$-Dicyclohexylcarbodiimide $(94.9 \mathrm{mg}, 0.460 \mathrm{mmol})$ in $\mathrm{CH}_{2} \mathrm{Cl}_{2}(5.0 \mathrm{~mL})$ was stirred at $0^{\circ} \mathrm{C}$ for 30 min under argon atmosphere. Then 3,5-di((pyridine-4yl)phenyl)-methanol (112.7 $\left.\mathrm{mg}, 0.430 \mathrm{mmol}\right)$ was added and stirred at room temperature for $36 \mathrm{~h}$. The reaction mixture was diluted with ethyl acetate $(10 \mathrm{~mL})$ and filtered. The mixture was dried over anhydrous sodium sulfate and evaporated under reduced pressure, and the residue was purified by column chromatography on silica gel $\left(\mathrm{CHCl}_{3}\right.$ :methanol $\left.=50: 1\right)$ to give the title compound as a white solid (124 mg, $0.286 \mathrm{mmol}$, yield 66.5\%). ${ }^{1} \mathrm{H}$ NMR (500 MHz, DMSO- $\left.d_{6}, 25^{\circ} \mathrm{C}\right) 8.66(\mathrm{~d}, 4 \mathrm{H}), 8.10(\mathrm{t}, 1 \mathrm{H}), 7.86$ $(\mathrm{m}, 6 \mathrm{H}), 7.33(\mathrm{~d}, 1 \mathrm{H}), 5.31(\mathrm{t}, 2 \mathrm{H}), 4.09(\mathrm{~m}, 1 \mathrm{H}), 1.13-1.31(12 \mathrm{H}) .{ }^{13} \mathrm{C}$ NMR $\left(500 \mathrm{MHz}\right.$, acetonitrile- $\left.d_{3}, 25^{\circ} \mathrm{C}\right) \delta 173.29$ (C), $155.22(\mathrm{C}), 150.34(\mathrm{CH}), 147.39(\mathrm{C}), 139.67(\mathrm{C}), 137.77(\mathrm{C}), 127.08(\mathrm{CH}), 125.62(\mathrm{CH}), 121.74(\mathrm{CH}), 79.96(\mathrm{C})$, $66.79\left(\mathrm{CH}_{2}\right), 49.39(\mathrm{CH}), 28.24\left(\mathrm{CH}_{3}\right)$ and $18.28\left(\mathrm{CH}_{3}\right)$. In Figures S1, S2 and $\mathrm{S} 3{ }^{1} \mathrm{H}$ NMR, ${ }^{13} \mathrm{C}$ NMR and Time of Flight Mass Spectroscopy (TOF-MS) (with a major peak at $\mathrm{m} / \mathrm{z}=434$ ) can be observed.

\section{Synthesis of L-Ligand}

A mixture of Boc-L-Ala-OH ( $85.1 \mathrm{mg}, 0.450 \mathrm{mmol}$ ) and $N, N^{\prime}$-Dicyclohexylcarbodiimide ( $\left.94.9 \mathrm{mg}, 0.460 \mathrm{mmol}\right)$ in $\mathrm{CH}_{2} \mathrm{Cl}_{2}(5.0 \mathrm{~mL})$ was stirred at $0{ }^{\circ} \mathrm{C}$ for 30 min under argon atmosphere. Then 3,5 - di((pyridine-4yl)phenyl)methanol $(112.7 \mathrm{mg}, 0.430 \mathrm{mmol}$ ) was added and stirred at room temperature for $36 \mathrm{~h}$ to obtain L-ligand (3,5di(pyridin-4-yl)benzyl (tert-butoxycarbonyl)-L-alaninate). The reaction mixture was diluted with ethyl acetate (10 $\mathrm{mL}$ ) and filtered. The mixture was dried over anhydrous sodium sulfate and evaporated under reduced pressure, and the residue was purified by column chromatography on silica gel $\left(\mathrm{CHCl}_{3}:\right.$ methanol $\left.=50: 1\right)$ to give the title compound as a white solid (114 mg, $0.268 \mathrm{mmol}$, yield $62.3 \%) .{ }^{1} \mathrm{H}$ NMR (500 MHz, DMSO- $\left.d_{6}, 25^{\circ} \mathrm{C}\right) 8.7(\mathrm{~d}, 4 \mathrm{H}), 8.10(\mathrm{t}, 1 \mathrm{H}), 7.85$ $(\mathrm{m}, 6 \mathrm{H}), 7.33(\mathrm{~d}, 1 \mathrm{H}), 5.29(\mathrm{t}, 2 \mathrm{H}), 4.09(\mathrm{~m}, 1 \mathrm{H}), 1.16-1.28(12 \mathrm{H}) .{ }^{13} \mathrm{C}$ NMR $\left(500 \mathrm{MHz}\right.$, acetonitrile- $\left.d_{3}, 25^{\circ} \mathrm{C}\right) \delta 173.32$ (C), $155.22(\mathrm{C}), 150.33(\mathrm{CH}), 147.36(\mathrm{C}), 139.66(\mathrm{C}), 137.73(\mathrm{C}), 127.06(\mathrm{CH}), 125.62(\mathrm{CH}), 121.71(\mathrm{CH}), 79.93(\mathrm{C})$, $66.78\left(\mathrm{CH}_{2}\right), 49.36(\mathrm{CH}), 28.26\left(\mathrm{CH}_{3}\right)$ and $18.27\left(\mathrm{CH}_{3}\right)$. Figures $\mathrm{S} 1$, S2 and S3 show ${ }^{1} \mathrm{H} \mathrm{NMR},{ }^{13} \mathrm{C}$ NMR and Time of Flight Mass Spectroscopy (TOF-MS) (with a major peak at $\mathrm{m} / \mathrm{z}=434$ ) for L-ligands.

\section{Synthesis of D-Pd ${ }_{12} \mathrm{~L}_{24}$ MOC}

Synthesis of D- $\mathrm{Pd}_{12} \mathrm{~L}_{24}$ with 12 equivalent $\mathrm{Pd}\left(\mathrm{NO}_{3}\right)_{2}$ and $24 \mathrm{D}$-ligands with a diameter of around $3.5 \mathrm{~nm}^{3}$ was conducted according to literature ${ }^{1}$ (Scheme S1 and Figure S3). Briefly, $8.97 \mathrm{mg}, 0.02 \mathrm{mmol}$ of the D-ligands and 2.3 $\mathrm{mg}, 0.01 \mathrm{mmol}$ of $\mathrm{Pd}\left(\mathrm{NO}_{3}\right)_{2}$ dissolved in $1 \mathrm{~mL}$ DMSO- $\mathrm{d}_{6}$ were added to a vial and purged with nitrogen. The reaction mixture was stirred at $70{ }^{\circ} \mathrm{C}$ overnight. ${ }^{1} \mathrm{H}$ NMR $\left(500 \mathrm{MHz}\right.$, DMSO- $\left.d_{6}, 25{ }^{\circ} \mathrm{C}\right) 9.49(\mathrm{br}, 96 \mathrm{H}), 8.38(\mathrm{bt}, 24 \mathrm{H}), 7.95(\mathrm{bd}$, $144 \mathrm{H}), 7.33(\mathrm{bd}, 24 \mathrm{H}), 5.34(\mathrm{br}, 48 \mathrm{H}), 3.97(\mathrm{br}, 24 \mathrm{H}), 1.08-1.28(288 \mathrm{H})$ (Figure S4). ${ }^{13} \mathrm{C}$ NMR $\left(500 \mathrm{MHz}, \mathrm{DMSO}-d_{6}, 25\right.$ $\left.{ }^{\circ} \mathrm{C}\right) \delta 173.4(\mathrm{C}), 155.73(\mathrm{C}), 151.71(\mathrm{CH}), 149.57(\mathrm{C}), 139.26(\mathrm{C}), 135.72(\mathrm{C}), 128.96(\mathrm{CH}), 124.82(\mathrm{CH})$, , $78.41(\mathrm{C})$, $65.38\left(\mathrm{CH}_{2}\right), 49.57(\mathrm{CH}), 28.30\left(\mathrm{CH}_{3}\right)$ and $17.03\left(\mathrm{CH}_{3}\right)$ (Figure $\left.\mathrm{S} 6\right)$.

\section{Synthesis of L-Pd ${ }_{12} \mathrm{~L}_{24}$ MOC}

L-Pd $\mathrm{Pd}_{12} \mathrm{~L}_{24}$ was synthesized using 12 equivalent $\mathrm{Pd}\left(\mathrm{NO}_{3}\right)_{2}$ and 24 L-ligands (Scheme S.1 and Figure S3). Briefly, 8.97 $\mathrm{mg}, 0.02 \mathrm{mmol}$ of the L-ligands and $2.3 \mathrm{mg}, 0.01 \mathrm{mmol}$ of $\mathrm{Pd}\left(\mathrm{NO}_{3}\right)_{2}$ dissolved in $1 \mathrm{~mL}$ DMSO- $\mathrm{d}_{6}$ were added to a vial 
and purged with nitrogen. The reaction mixture was stirred at $70{ }^{\circ} \mathrm{C}$ overnight. ${ }^{1} \mathrm{H}$ NMR $\left(500 \mathrm{MHz}, \mathrm{DMSO}-d_{6}, 25^{\circ} \mathrm{C}\right)$ 9.49 (br, 96H), 8.37 (bt, 24H), 7.99 (bd, 144H), 7.34 (bd, 24H), 5.29 (br, 48H), 3.97 (br, 24H), 1.08-1.28 (288H). ${ }^{13} \mathrm{C}$ NMR (500 MHz, DMSO- $\left.d_{6}, 25^{\circ} \mathrm{C}\right) \delta 173.44$ (C), $155.76(\mathrm{C}), 151.78(\mathrm{CH}), 149.53(\mathrm{C}), 139.28(\mathrm{C}), 135.74(\mathrm{C}), 129.12$ $(\mathrm{CH}), 124.97(\mathrm{CH})$, , $78.46(\mathrm{C}), 65.41\left(\mathrm{CH}_{2}\right), 49.63(\mathrm{CH}), 28.30\left(\mathrm{CH}_{3}\right)$ and $17.01\left(\mathrm{CH}_{3}\right)$ (Figure $\left.\mathrm{S} 6\right)$. Chirality of ligands and cages was confirmed by circular dichroism (CD) spectra (Figure S4).

\section{Supporting Data and Figures}
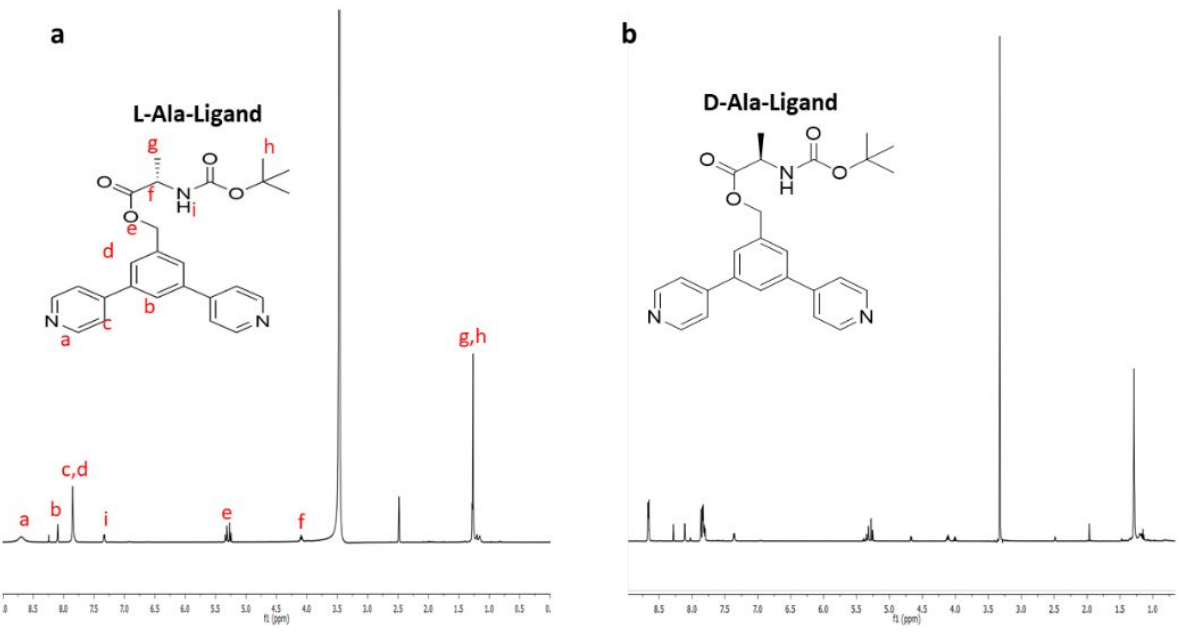

Figure S1. ${ }^{1} \mathrm{H}$ NMR spectra of D- and L-ligands
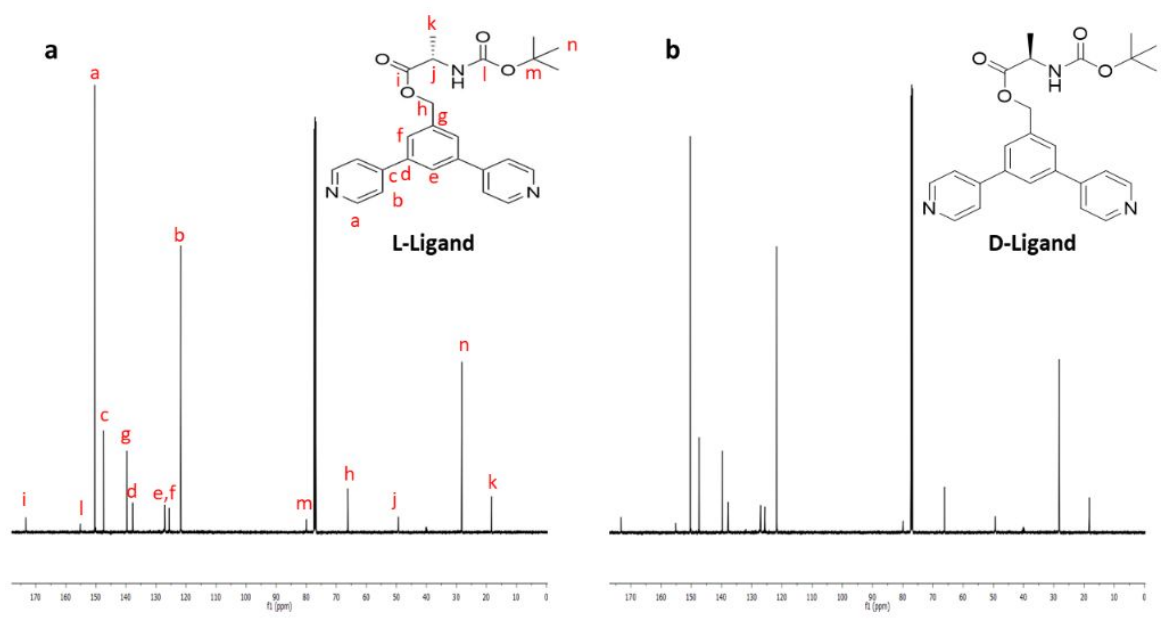

Figure S2. ${ }^{13} \mathrm{C}$ NMR spectra of D- and L-ligands 

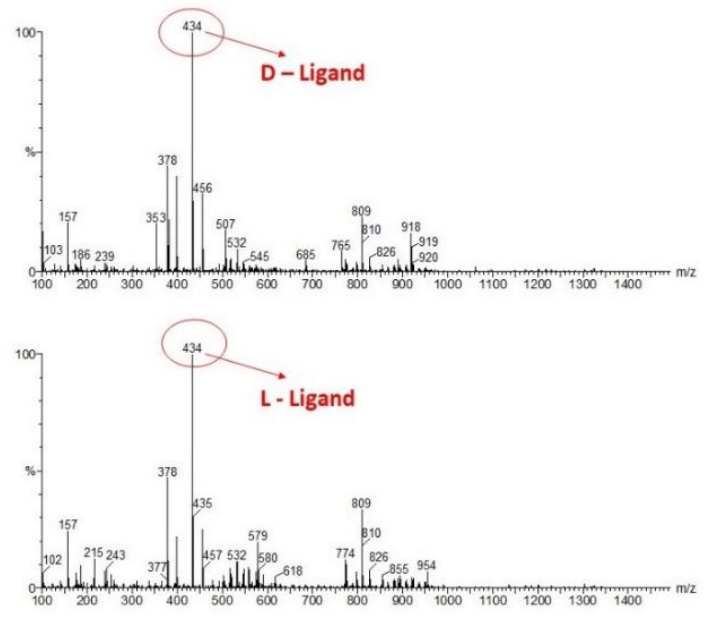

Figure S3. Time of Flight Mass Spectroscopy (TOF-MS) of the enantiomers of the ligands

a

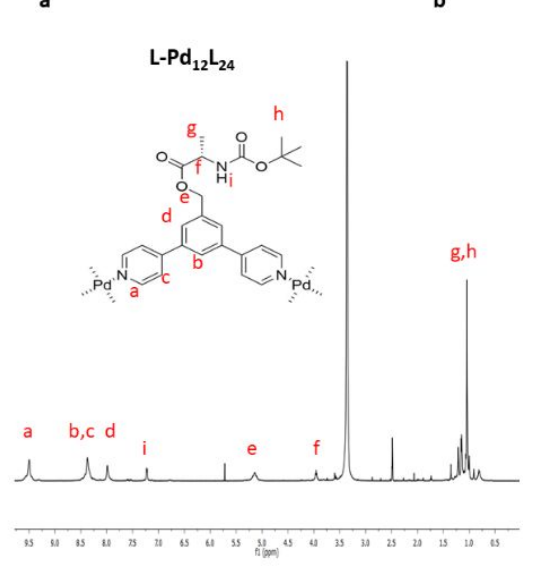

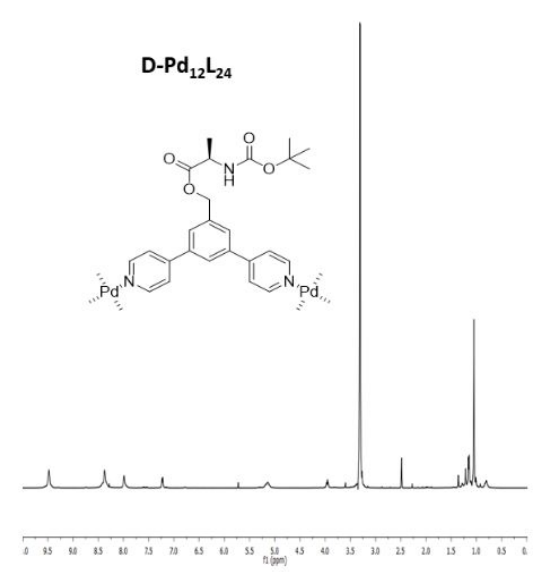

Figure S4. ${ }^{1} \mathrm{H}$ NMR spectra of both enantiomers of $\mathrm{Pd}_{12} \mathrm{~L}_{24}$

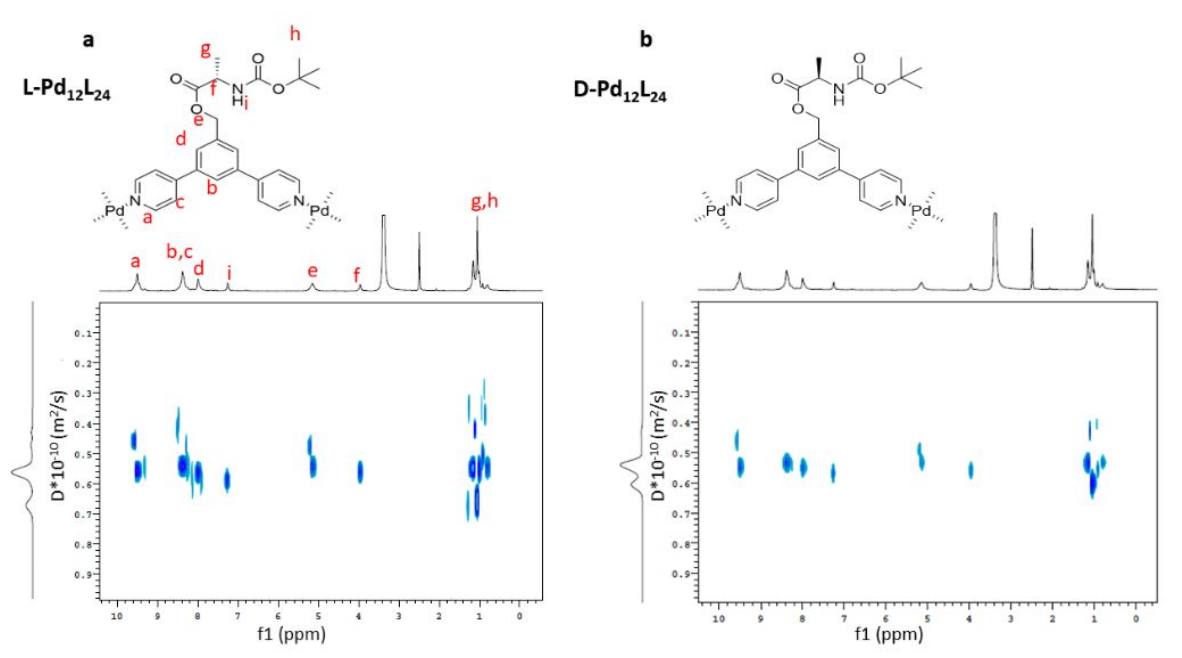

Figure S5. ${ }^{1} \mathrm{H}$ DOSY NMR spectra of both enantiomers of $\mathrm{Pd}_{12} \mathrm{~L}_{24}$ 


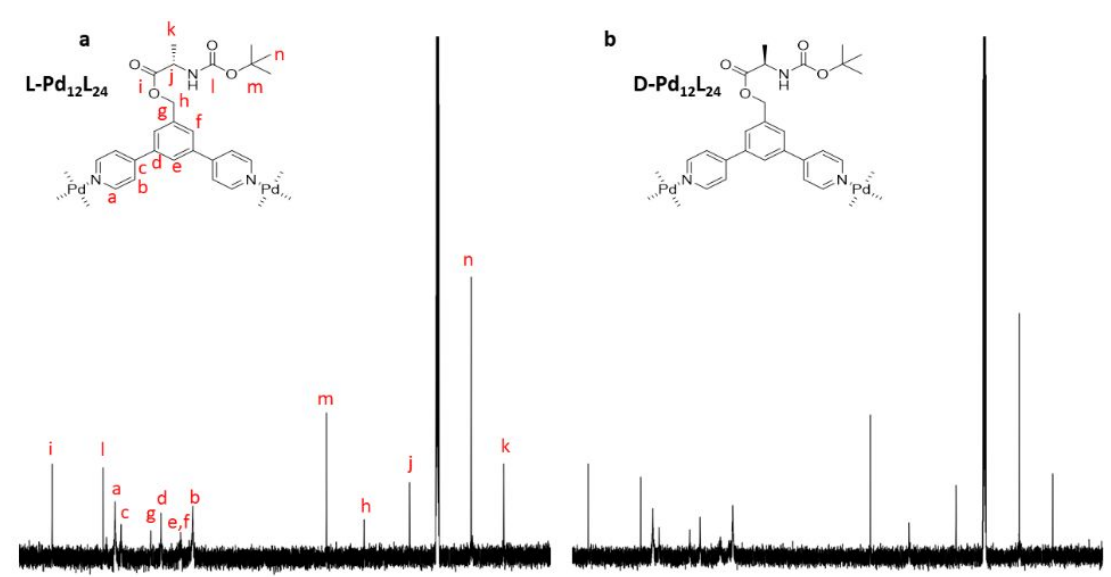

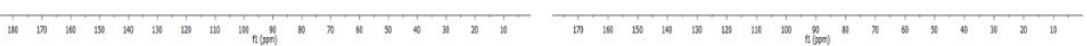

Figure S6. ${ }^{13} \mathrm{C}$ NMR spectra of D- and L-Pd ${ }_{12} \mathrm{~L}_{24}$

a

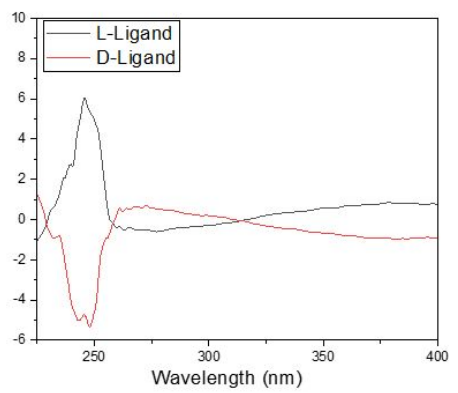

b

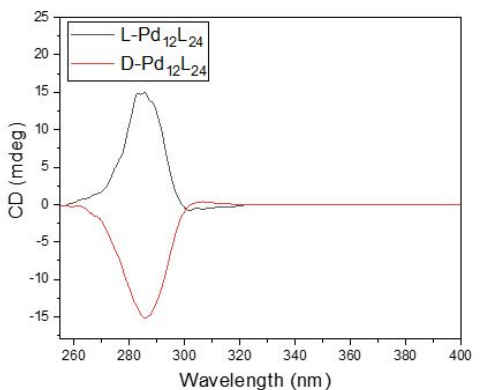

Figure S7. CD spectra of chiral (a) D- and L-ligands and (b) D- and L-Pd ${ }_{12} \mathrm{~L}_{24}$ MOCs

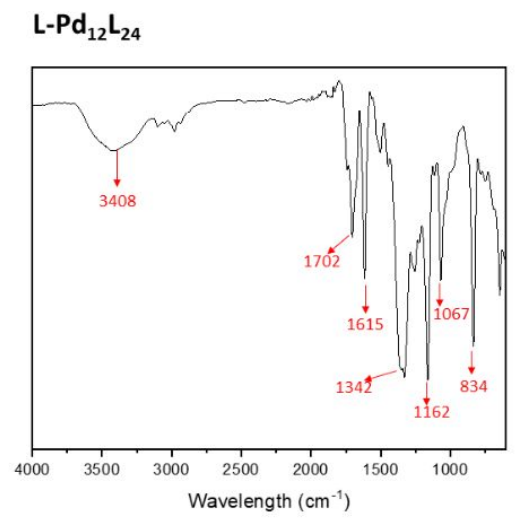

$$
\text { D-Pd } \mathrm{P}_{12} \mathrm{~L}_{24}
$$

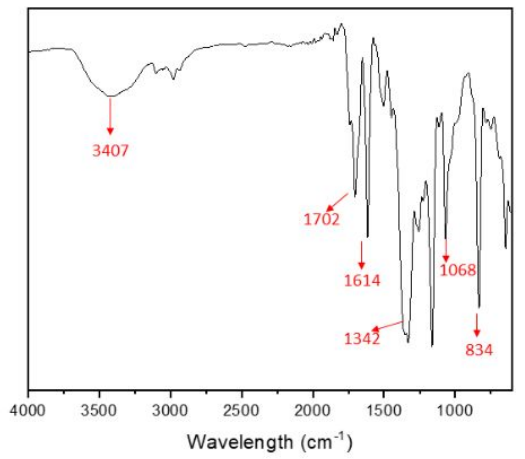

Figure S8. Fourier transform infrared (FTIR) spectroscopy of D- and L- $\mathrm{Pd}_{12} \mathrm{~L}_{24} \mathrm{MOCs}$, indicating several bending and stretching of chemical bonds in the MOCs' structure, including: stretching of $\mathrm{C}=\mathrm{O}, \mathrm{C}=\mathrm{C}, \mathrm{C}-\mathrm{N}, \mathrm{C}-\mathrm{O}$, and bending of $\mathrm{N}-\mathrm{H}$ and $\mathrm{C}-\mathrm{H}$. 

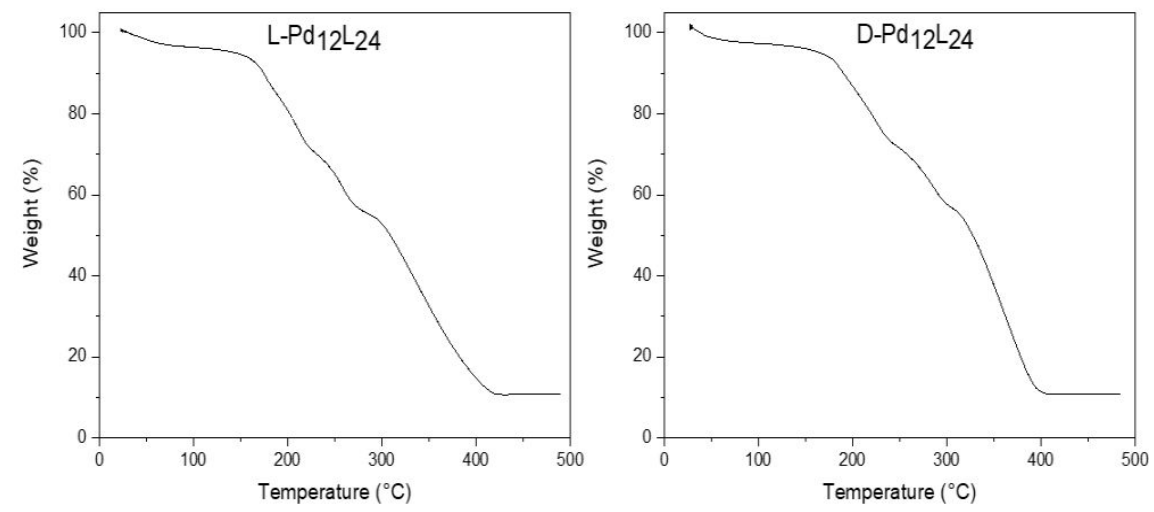

Figure S9. Thermogravimetric analysis (TGA) curves of L- and D-Pd $\mathrm{H}_{12} \mathrm{~L}_{24}$

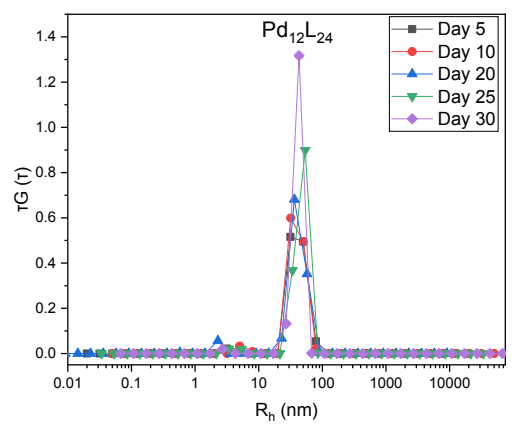

Figure S10. CONTIN analysis of the self-assembled blackberry structures by $\operatorname{Pd}_{12} \mathrm{~L}_{24}$ MOCs at 90 degree during the self-assembly time period indicating the assembly size remains constant during this time.
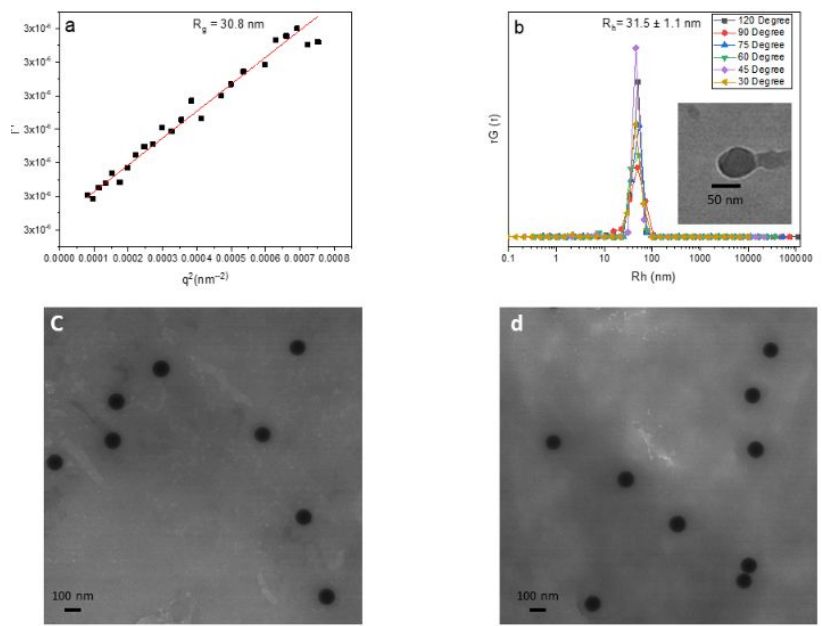

Figure S11. (a) SLS results and (b) CONTIN analysis for Boc-L-Ala/D-Pd ${ }_{12} \mathrm{~L}_{24}=120$ (smallest blackberry structure was taken as an example to meet the $q R_{g}<<1$ requirement ${ }^{4}$ for $\mathrm{R}_{\mathrm{g}}$ measurement by SLS). $R_{g} / R_{h} \sim 1$; thus, hollow spherical blackberrytype structure is formed ${ }^{5,6}$. TEM image of the blackberry structures formed by (c) D-Pd ${ }_{12} \mathrm{~L}_{24}$ and (d) $\mathrm{L}-\mathrm{Pd}_{12} \mathrm{~L}_{24}$ 


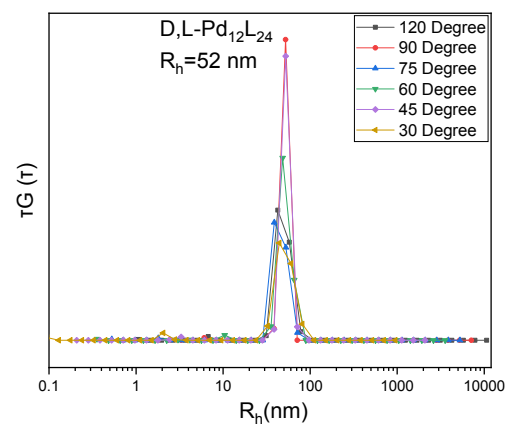

Figure S12. CONTIN analysis of the self-assembled blackberry structures by racemic mixture of D,L-Pd ${ }_{12} \mathrm{~L}_{24} 0.25+0.25$ $\mathrm{mg} / \mathrm{mL}$ solution

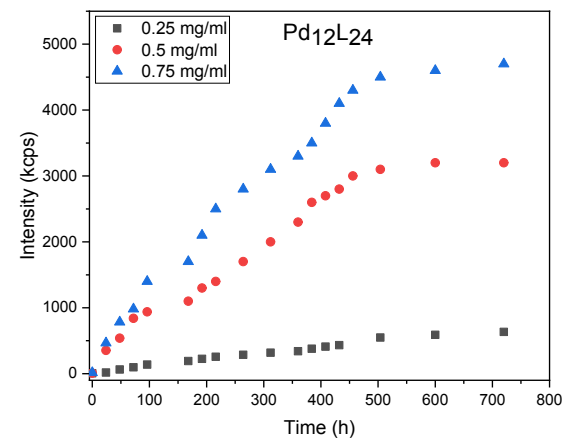

Figure S13. SLS data for $\mathrm{Pd}_{12} \mathrm{~L}_{24}$ with different concentrations indicating a concentration dependent self-assembly behavior of the MOCs

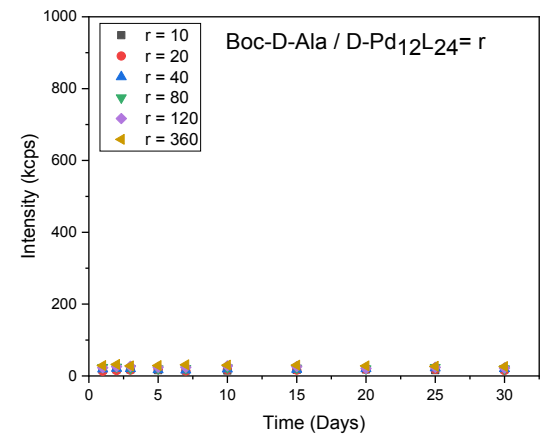

Figure S14. Time-resolved SLS measurements of D- $\mathrm{Pd}_{12} \mathrm{~L}_{24}$ MOCs when Boc-Ala is present in the self-assembly environment without any extra nitrate anions added 

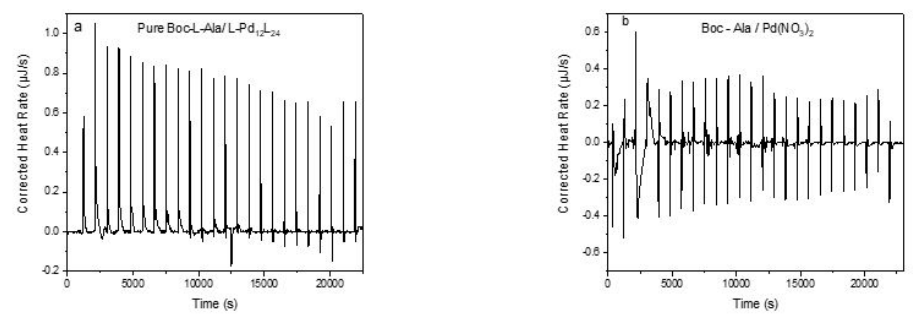

Figure S15. ITC results for titrating (a) pure Boc-Ala to $\mathrm{Pd}_{12} \mathrm{~L}_{24}$, (b) Boc-Ala to $\mathrm{Pd}\left(\mathrm{NO}_{3}\right)_{2}$
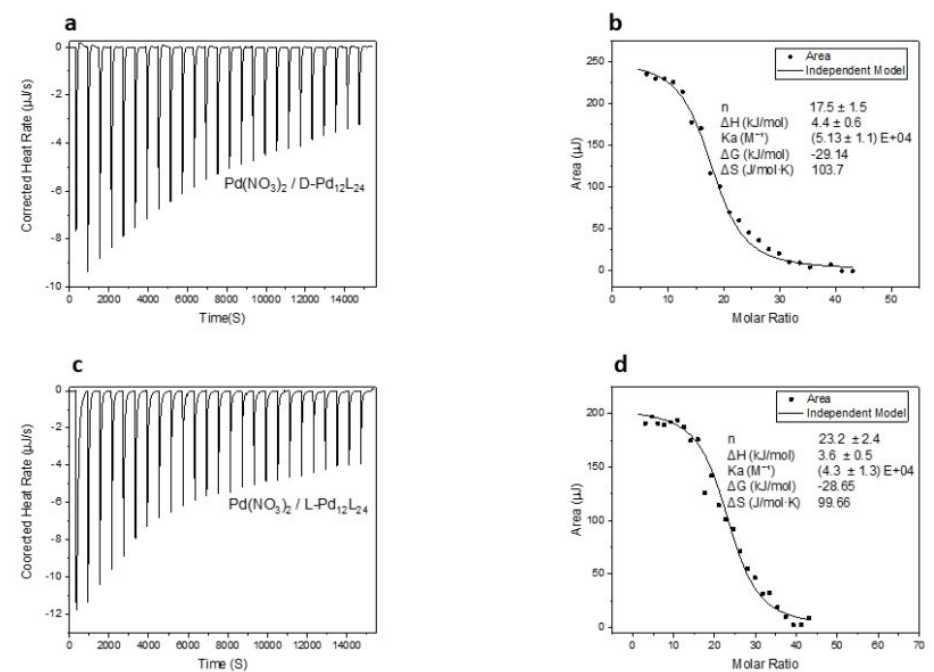

Figure S16. ITC results for titrating ( $\mathrm{a}$ and b) $\mathrm{Pd}\left(\mathrm{NO}_{3}\right)_{2}$ to D-Pd $\mathrm{Pd}_{12} \mathrm{~L}_{24}$ and (c and d) $\mathrm{Pd}\left(\mathrm{NO}_{3}\right)_{2}$ to $\mathrm{L}-\mathrm{Pd}_{12} \mathrm{~L}_{24}$
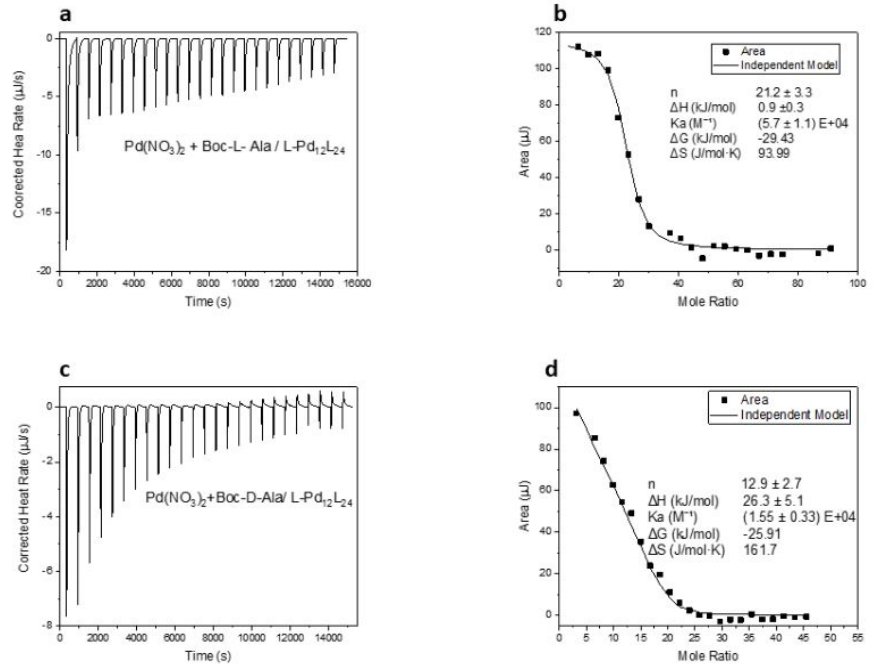

Figure S17. ITC measurements and fitted data to independent model for heat area data for titrating (a and b) mixture of Boc-L-Ala and $\mathrm{Pd}\left(\mathrm{NO}_{3}\right)_{2}$ and (c and d) mixture of Boc-D-Ala and $\mathrm{Pd}\left(\mathrm{NO}_{3}\right)_{2}$ to $\mathrm{L}-\mathrm{Pd}_{12} \mathrm{~L}_{24}$ 

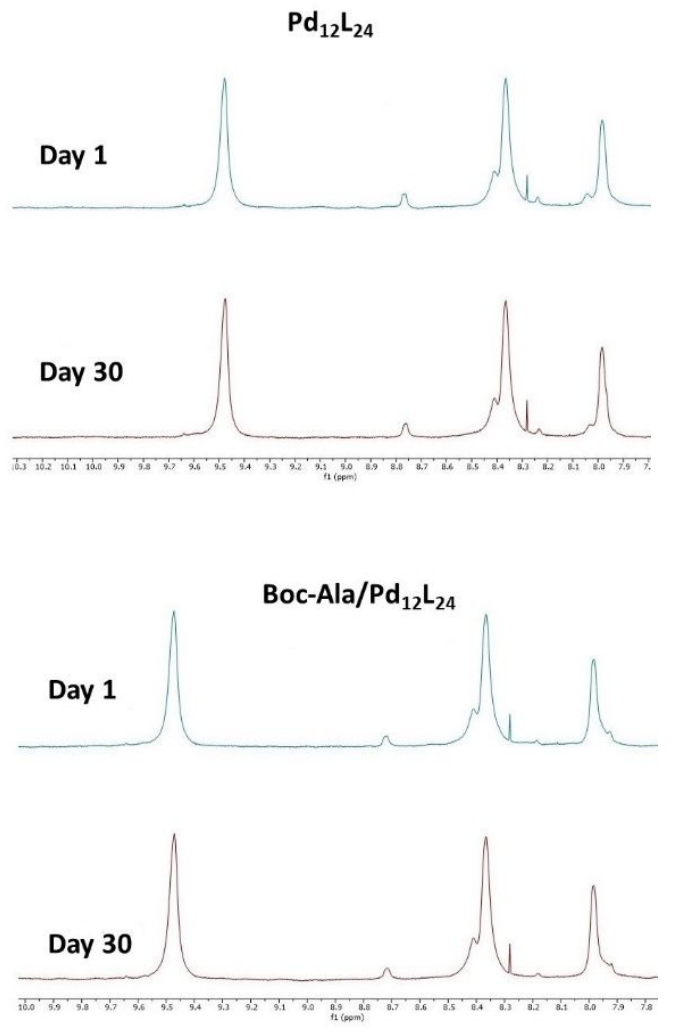

Figure S18. Stability test of $\mathrm{Pd}_{12} \mathrm{~L}_{24}$ cages in the presence of Boc-Ala by ${ }^{1} \mathrm{H}$ NMR in a 30 days period

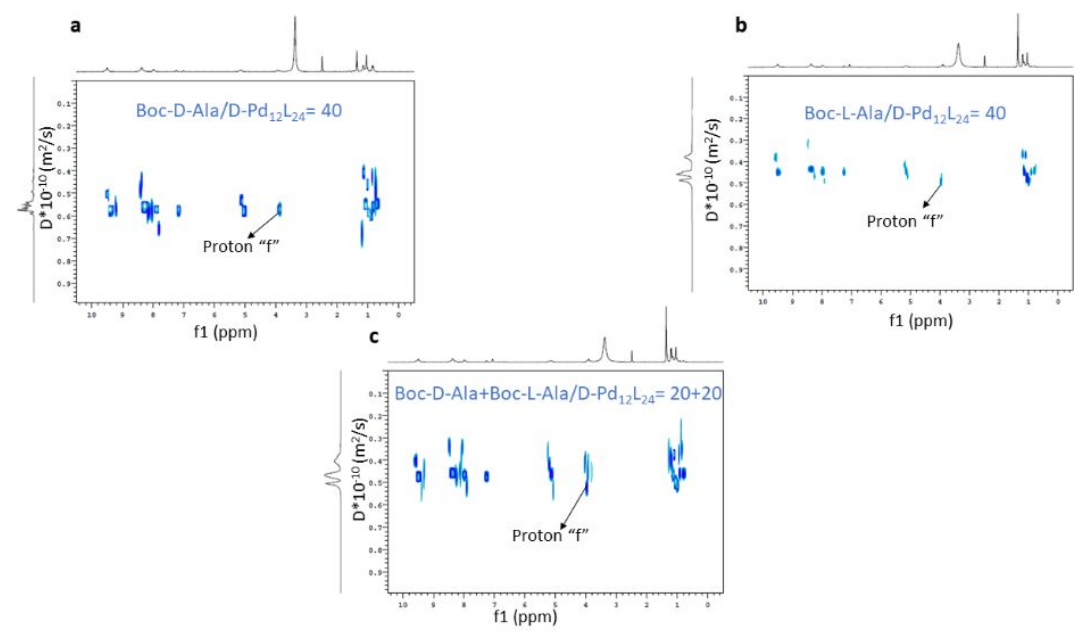

Figure S19. ${ }^{1} \mathrm{H}$ NMR DOSY data for a) Boc-D-Ala/D-Pd ${ }_{12} \mathrm{~L}_{24}=40$ (liked-pair) b) Boc-L-Ala/D-Pd ${ }_{12} \mathrm{~L}_{24}=40$ (disliked-pair) and c) mixture of Boc-D-Ala and Boc-L-Ala with a molar ratio of 20 for each

\section{Calculation of Hydrodynamic Radius $\left(R_{h}\right)$ of D- and L-Pd ${ }_{12} L_{24}$ cages}

In order to calculate the $R_{h}$ of the cages, we used diffusion constant value corresponding to the proton labeled "d" in Figure S5; because, it belongs to the aromatic ring (rigid part) of the cages' ligands. Stokes-Einstein equation ${ }^{7}$ is used as below:

$R_{h}=\frac{k_{b} T}{6 \pi \mu D}$

(eq. S1) 
in which $R_{h}, k_{b}, T, \mu$ and $D$ are hydrodynamic radius, Boltzman's constant $\left(1.38 \times 10^{-23} \mathrm{~N} \cdot \mathrm{m} \cdot \mathrm{k}^{-1}\right)$, absolute temperature $(\mathrm{k})$, viscosity (1.99 N.m-2.s) and diffusion coefficient $\left(\mathrm{m}^{2} . \mathrm{s}^{-1}\right)$. The D values for D- and $\mathrm{L}^{-} \mathrm{Pd}_{12} \mathrm{~L}_{24}$ is $0.5497 \times 10^{-10}$ and $0.5816 \times 10^{-}$ ${ }^{10} \mathrm{~m}^{2} \cdot \mathrm{s}^{-1}$ respectively, corresponding to $\mathrm{R}_{\mathrm{h}}$ of $\sim 2$ and $1.9 \mathrm{~nm}$.

\section{The Effect of Other Chiral Counterions on The Self-Assembly of $\operatorname{Pd}_{12} L_{24}$ MOCs}

Intensity increment during the self-assembly of D-Pd $\mathrm{P}_{12} \mathrm{~L}_{24}$ MOCs was investigated when chiral counterions other than Boc-Ala, such as malic acid and tartaric acid were present in the self-assembly environment (Figures 5.a and b). It can be seen that switching their chirality from D-malic (tartaric) acid to L-malic (tartaric) acid decreased the selfassembly rate. In addition, hydrodynamic radius at zero angle was smaller for the disliked-pairs $\left(\mathrm{D}-\mathrm{Pd} \mathrm{d}_{12} \mathrm{~L}_{24} / \mathrm{L}\right.$-malic (tartaric) acid). In the case of liked-pairs $\mathrm{R}_{\mathrm{h}, 0}$ for the blackberry structures is $56 \mathrm{~nm}$ and $53 \mathrm{~nm}$ for malic acid and tartaric acid respectively; while, it is $40 \mathrm{~nm}$ ( for malic acid) and $44 \mathrm{~nm}$ (for tararic acid) for the disliked-pairs. Using equation 1, indicated that the self-assembly was suppressed by $\sim 22 \%$ and $\sim 35 \%$ in the disliked-pairs of malic acid and tartaric acid, respectively when compared to their liked-pairs.

Although other chiral weak acids such as malic acid and tartaric acid in a disliked-pair are capable to suppress the self-assembly of $\mathrm{Pd}_{12} \mathrm{~L}_{24}$ macroions and decrease the size of the blackberry structures, alanine has the highest impact on the self-assembly suppression (by 67\%) when compared to the other effective chiral counterions (e.g $22 \%$ and $35 \%$ for malic acid and tartaric acid, respectively) meaning that among all the disliked-pairs MOC (containing alanine in the ligands)-alanine is the most effective pair to weaken the binding strength between nitrate and $\mathrm{Pd}_{12} \mathrm{~L}_{24} \mathrm{MOCs}$ and increasing dimer/oligomer activation energy when compared to the other effective pairs such as $\mathrm{Pd}_{12} \mathrm{~L}_{24}-\mathrm{malic}$ acid (or tartaric acid).
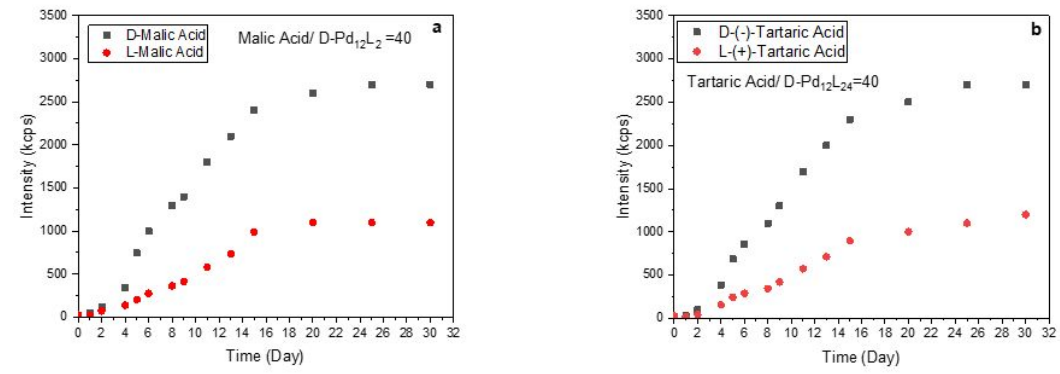

Figure S20. SLS time-resolved intensity measurement during the self-assembly of D- $\mathrm{Pd}_{12} \mathrm{~L}_{24}$ when enantiomers of Malic Acid (a) and Tartaric Acid (b) are present in the self-assembly environment 


\section{Supporting References}

(1) Zhukhovitskiy, A. V; Zhong, M.; Keeler, E. G.; Michaelis, V. K.; Sun, J. E. P.; Hore, M. J. A.; Pochan, D. J.; Griffin, R. G.; Willard, A. P.; Johnson, J. A. Highly Branched and Loop-Rich Gels via Formation of Metal-Organic Cages Linked by Polymers. Nat. Chem. 2015, $8,33$.

(2) Suzuki, K.; Kawano, M.; Sato, S.; Fujita, M. Endohedral Peptide Lining of a Self-Assembled Molecular Sphere To Generate Chirality-Confined Hollows. J. Am. Chem. Soc. 2007, 129, 10652-10653.

(3) Li, H.; Luo, J.; Liu, T. Modification of the Solution Behavior of Pd12L24 Metal-Organic Nanocages via PEGylation. Chem. - A Eur. J. 2016, 22, 17949-17952.

(4) Hiemenz, P. C. R. Rajagopalan Principles of Colloid and Surface Chemistry. Electr. Double Layer Double-Layer Interact. 1997, 509-510.

(5) Liu, T.; Diemann, E.; Li, H.; Dress, A. W. M.; Müller, A. Self-Assembly in Aqueous Solution of Wheel-Shaped Mo154 Oxide Clusters into Vesicles. Nature 2003, 426, 59-62.

(6) Yin, P.; Li, D.; Liu, T. Solution Behaviors and Self-Assembly of Polyoxometalates as Models of Macroions and Amphiphilic Polyoxometalate-Organic Hybrids as Novel Surfactants. Chem. Soc. Rev. 2012, 41, 7368-7383.

(7) Dill, K.; Bromberg, S. Molecular Driving Forces: Statistical Thermodynamics in Biology, Chemistry, Physics, and Nanoscience; Garland Science, 2012. 